\section{An Evaluation of Summer Cover Crops for Use in Vegetable Production Systems in North Carolina}

\author{
Nancy G. Creamer ${ }^{1}$ and Keith R. Baldwin ${ }^{2}$ \\ Department of Horticultural Science, North Carolina State University, Box \\ 7609, Raleigh, NC 27695
}

Additional index words. Glycine max, Vigna unguiculata, Sesbania, Lablab purpureus, Mucuna deeringiana, Sorghum sudanense, S. bicolor x S. sudanense, Pennisetum glaucum, Setaria italica, Echinochloa frumentacea, Fagopyrum esculentum, Sesamum indicum, nitrogen, weeds

\begin{abstract}
Summer cover crops can produce biomass, contribute nitrogen to cropping systems, increase soil organic matter, and suppress weeds. Through fixation of atmospheric $N_{2}$ and uptake of soil residual $N$, they also contribute to the $N$ requirement of subsequent vegetable crops. Six legumes \{cowpea (Vigna unguiculata $\mathrm{L}$.), sesbania (Sesbania exaltata L.), soybean (Glycine max L.), hairy indigo (Indigofera hirsutum L.), velvetbean [Mucuna deeringiana (Bort.) Merr.], and lablab (Lablab purpureus L.)\}; two nonlegume broadleaved species [buckwheat (Fagopyrum esculentum Moench) and sesame (Sesamum indicum L.)]; and five grasses \{sorghum-sudangrass [Sorghum bicolor (L) Moench $\mathrm{x} S$. sudanense (P) Stapf.], sudangrass [S. sudanense (P) Stapf.], Japanese millet [Echinochloa frumentacea (Roxb.) Link], pearl millet [Pennisetum glaucum (L). R. Br.], and German foxtail millet [Setaria italica (L.) Beauv.)]\}, were planted in raised beds alone or in mixtures in 1995 at Plymouth, and in 1996 at Goldsboro, N.C. Biomass production for the legumes ranged from 1420 (velvetbean) to $4807 \mathrm{~kg} \cdot \mathrm{ha}^{-1}$ (sesbania). Low velvetbean biomass was attributed to poor germination in this study. Nitrogen in the aboveground biomass for the legumes ranged from 32 (velvetbean) to $97 \mathrm{~kg} \cdot \mathrm{ha}^{-1}$ (sesbania). All of the legumes except velvetbean were competitive with weeds. Lablab did not suppress weeds as well as did cover crops producing higher biomass. Aboveground biomass for grasses varied from

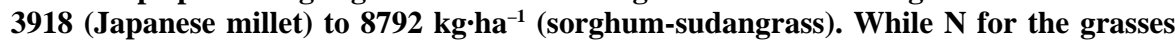
ranged from 39 (Japanese millet) to $88 \mathrm{~kg} \cdot \mathrm{ha}^{-1}$ (sorghum-sudangrass), the $\mathrm{C}: \mathrm{N}$ ratios were very high. Additional $N$ would be needed for fall-planted vegetable crops to overcome immobilization of $\mathbf{N}$. All of the grass cover crops reduced weeds as relative to the weedy control plot. Species that performed well together as a mixture at both sites included Japanese millet/soybean and sorghum-sudangrass/cowpea.
\end{abstract}

The changing emphasis in agriculture is toward optimizing economic and biological productivity, while minimizing the impact of agriculture on the environment. Thus, there is growing interest in using short-season summer annual legumes, other broadleaves, and/or grasses as cover crops and green manures in vegetable production systems. While substantial research has been conducted on winter annual cover crops, very little has been conducted on summer cover crops. Summer cover

Received for publication 3 May 1999. Accepted for publication 13 Sept. 1999. We thank the Organic Farming Research Foundation for funding this evaluation of summer cover crop species. We also thank Jane Frampton, Joe Difeo, and Tim Mathews for their technical support, and the staff at the Tidewater Research Station in Plymouth and the Center for Environmental Farming Systems in Goldsboro for their field support. The cost of publishing this paper was defrayed in part by the payment of page charges. Under postal regulations, this paper therefore must be hereby marked advertisement solely to indicate this fact.

1'Assistant Professor. E-mail: nancy_creamer@ ncsu.edu

${ }^{2}$ Extension Associate. E-mail address: keith_ baldwin@ncsu.edu crops can be used in the southeastern United States between spring and fall vegetable crops.

Cover crops can provide a source of $\mathrm{N}$ for subsequent crops (Peoples et al., 1995), reduce erosion (Flach, 1990), reduce runoff and potential contamination of surface waters (Hoyt et al., 1994), capture soil mineral $\mathrm{N}$ that might otherwise be lost to leaching (Stivers and Shennan, 1989), improve soil physical properties (Barber and Navarro, 1994; Wilson et al., 1982), suppress nematode populations (Crow et al., 1996; McSorley et al., 1994; McSorley and Dickson, 1995; Mojtahedi et al., 1993), and suppress weeds (Creamer et al., 1996; Sanford and Hirston, 1984; Weston et al., 1989).

Summer annual legumes with potential for inclusion in vegetable production rotations include soybean, cowpea, sesbania, and lablab or hyacinth bean, velvetbean, sunnhemp (Crotalariajuncea L.), and hairy indigo. Grasses and other nonlegumes that could be considered by growers as sole rotation crops or for inclusion in summer legume-grass mixtures are sudangrass, sorghum-sudangrass, pearl millet, German foxtail millet, Japanese millet, buckwheat, and sesame.

Aboveground biomass and biomass $\mathrm{N}$ vary considerably within species. Generally, legume biomass and biomass $\mathrm{N}$ increase as duration of growth increases. Franzluebbers et al. (1994) reported that $\mathrm{N}$ accumulated in 7-week-old cowpea was double that accumulated in 5week-old plants.

For biomass $\mathrm{N}$ to be used by subsequent crops, it must undergo mineralization. Wide variations in the chemical composition of plant residues exist (Clement et al., 1995); hence, mineralization rates of residues can also be expected to vary widely. Beri et al. (1989) reported that $65 \%$ to $70 \%$ of the $\mathrm{C}$ in cowpea and sunnhemp residues $(\mathrm{C}: \mathrm{N}=32$ and 24 , respectively) and $50 \%$ to $55 \%$ of sesbania and clusterbean [Cyampopsis tetragonoloba (L.) Taub.] residues ( $\mathrm{C}: \mathrm{N}=22$ for both) was mineralized in the first 2 weeks after soil incorporation. High-quality legume residues decompose quickly. Litterbag studies suggest that $\approx 50 \%$ to $80 \%$ of the added residue $\mathrm{N}$ is released under temperate conditions during the first subsequent crop cycle (Wagger, 1989). However, Giller and Cadisch (1995) reported that only $9 \%$ to $29 \%$ of the added green manure $\mathrm{N}$ was recovere by the first catch crop in temperate regions, and only $6 \%$ to $28 \%$ in tropical agricultural systems.

Synchronization of $\mathrm{N}$ supply from decomposing residue and crop $\mathrm{N}$ demand should increase the overall efficiency of use (McGill and Myers, 1987). Appropriate timing of cover crop kill affects this synchronization (Wagger, 1989). The mixing of residues of different quality may be one approach to managing rates of decomposition and $\mathrm{N}$ release that can help to optimize the efficiency with which fixed $\mathrm{N}_{2}$ is used. Creamer et al. (1997) studied the use of winter cover crop mixtures to optimize benefits associated with cover crop use. They attempted to achieve a more desirable $\mathrm{C}: \mathrm{N}$ ratio of residue material by combining plants with high (mature cereals) and low (legumes) $\mathrm{C}: \mathrm{N}$ ratios to reduce $\mathrm{N}$ mineralization rate and to time $\mathrm{N}$ release with crop $\mathrm{N}$ uptake. Planting mixtures of legumes and grasses may also increase the amount of atmospheric $\mathrm{N}_{2}$ fixed by the legume. Grasses usually germinate and establish effective root systems more rapidly than do legumes. Thus, the soil $\mathrm{N}$ concentration will be reduced, resulting in increased legume nodulation and $\mathrm{N}_{2}$ fixation (Giller and Cadisch, 1995).

Weed control in vegetable production systems is difficult because few herbicides are registered. Weeds are typically controlled by a management system consisting of a combination of tillage and herbicides. Tillage can reduce soil surface residue and increase the risk of soil erosion, and herbicides can be costly and, if misused, contaminate water resources. Alternative weed management strategies include the use of both cover crops and cover crop residues as mulches to effectively suppress weed seed germination and emergence (Teasdale, 1993). Mechanisms for this inhibition include crop/weed competition while the cover crop is growing, allelopathy, and alteration of the soil physical environment, e.g., changes in light availability, soil temperature, and soil moistures (Creamer et al., 1997). 
When killed and left as a mulch on the soil surface, cover crops can provide $\mathrm{N}$ for fall vegetable crops and serve as a weed-suppressing mulch into which fall vegetable crops can be transplanted without tillage. Schonbeck et al. (1991) grew sequential combinations of winter and summer cover crops and found that some buckwheat plantings suppressed summer weeds effectively, but others failed because of drought. Sudangrass tolerated drought, but grew rapidly and suppressed weeds only at the most fertile site. Regrowth of buckwheat in lettuce (Lactuca sativa L.) was a problem.

Short sudangrass $(15 \mathrm{~cm})$ killed with glyphosate [N-(phosphonomethyl) glycine] had no effect on fall-planted cabbage (Brassica oleracea L. Capitata), but taller sudangrass $(30 \mathrm{~cm})$ reduced cabbage yields, possibly because of increased allelopathic exudates (Knavel and Herron, 1985). Sorghumsudangrass seedlings exude sorgoleone from roots. At very low concentrations, Einhellig et al. (1993) showed that sorgoleone inhibited photosyntheseis in sensitive plants like soybean and pea (Pisum sativum L.). Weston et al. (1989) reported that the allelopathic potential of sorghum-sudangrass diminished with age.

This study was conducted to evaluate several potential summer cover crops and mixtures for use in a vegetable production rotations. Cover crops were evaluated for production of aboveground biomass, $\mathrm{N}$ in aboveground biomass, $\mathrm{C}: \mathrm{N}$ ratio (as an indication of availability of $\mathrm{N}$ to subsequent crops), suppression of weeds, and degree of active nodulation of legumes. Ultimately, the goal was to select single species and mixtures that would produce high biomass and $\mathrm{N}$, have a desirable $C: N$ ratio (20:1-30:1), and could be mechanically killed and managed to suppress weeds both while growing and in a subsequent fall vegetable crop.

\section{Materials and Methods}

Cover crop plots were established in Plymouth, N.C., on 21 June 1995, and at Goldsboro, N.C., on 3 July 1996. Soil in Plymouth was a Cape Fear (clayey, mixed, thermic Typic Umbraquults) with $16 \%$ organic matter and pH 5.3. In Goldsboro, soil was an Altavista (fine-loamy, mixed, thermic
Aquic Hapludults) with $0.3 \%$ organic matter and $\mathrm{pH} 5.7$.

Soil was disked and raised beds $1.5 \mathrm{~m}$ wide were formed with a rototiller/bedshaper. North Carolina Dept. of Agriculture \& Consumer Services soil tests indicated adequate levels of $\mathrm{P}$ and $\mathrm{K}$, so no supplemental fertilizer was applied at either location. Cover crops were seeded at recommended rates (Table 1) with a small-plot precision drill. The experimental design was a randomized complete-block with four replications. Each plot consisted of three beds $4.5-\mathrm{m}$ wide $\times$ 6-m long. Seeding rates for mixtures were selected based on $60 \%$ of the monoculture seeding rate for legumes and $40 \%$ of the seeding rates for grasses. All legumes were inoculated with the appropriate Rhizobium species. General characteristics of cover crop species evaluated are listed in Table 2.

Nodules from five randomly selected

Table 1. Seeding rates of summer cover crops and cover crop mixtures planted in Plymouth (1995) and Goldsboro (1996), N.C.

\begin{tabular}{|c|c|c|}
\hline$\underline{\text { Species }}$ & Scientific name & $\begin{array}{c}\text { Seeding rate } \\
\left(\mathrm{kg} \cdot \mathrm{ha}^{-1}\right)\end{array}$ \\
\hline \multicolumn{3}{|c|}{ Legumes and other broadleaves } \\
\hline Cowpea 'Iron Clay' & Vigna unguiculata $\mathrm{L}$. & 78 \\
\hline Sesbania & Sesbania exaltata $\mathrm{L}$. & 22 \\
\hline Hairy Indigo & Indigofera hirsuta $\mathrm{L}$. & 9 \\
\hline Soybean: yellow 'Young' & Glycine $\max (\mathrm{L}$.$) Merrill$ & 100 \\
\hline Soybean: black seeded (trailing) 'Laredo' & Glycine $\max (\mathrm{L}$.$) Merrill$ & 34 \\
\hline Velvetbean & Mucuna deeringiana (Bort.) Merr. & 45 \\
\hline Lablab & Lablab purpureus (L.) Sweet & 45 \\
\hline Buckwheat & Fagopyrum esculentum Moench & 67 \\
\hline Sesame $^{\mathrm{z}}$ & Sesamum indicum $\mathrm{L}$. & 13 \\
\hline \multicolumn{3}{|c|}{ Grasses } \\
\hline Japanese millet & Echinochloa frumentacea (Roxb.) Link & 34 \\
\hline Pearl milet & Pennisetum glaucum (L.) R. Br. & 34 \\
\hline German foxtail millet & Setaria italica (L.) Beauv. & 34 \\
\hline Sudangrass & Sorghum sudanense L. & 39 \\
\hline Sorghum-sudangrass & $\begin{array}{l}\text { Sorghum bicolor }(\mathrm{L}) \text { Moench } \mathrm{x} \\
\text { Sorghum sudanense }(\mathrm{P}) \text { Stapf. }\end{array}$ & 39 \\
\hline \multicolumn{3}{|c|}{ Mixtures } \\
\hline Soybean (trailing)/sorghum-sudangrass & & $24 / 12$ \\
\hline Cowpea/sorghum-sudangrass & & $55 / 12$ \\
\hline Cowpea/sesbania $^{z}$ & & $55 / 7$ \\
\hline Soybean/Japanese millet & & $60 / 13$ \\
\hline Velvetbean/sesbania ${ }^{2}$ & & $31 / 7$ \\
\hline Velvetbean/pearl millet ${ }^{y}$ & & $27 / 13$ \\
\hline Velvetbean/sorghum-sudangrass ${ }^{y}$ & & $27 / 16$ \\
\hline
\end{tabular}

${ }^{2}$ Seeded in Goldsboro only.

${ }^{y}$ Seeded in Plymouth only. plants per treatment were subjectively rated as described by Sarrantonio (1991) for size (small, medium, large), location (taproot, lateral root, both), and activity (not active, some active, all active) on 7 Aug. 1995. Some of these species of legumes had never been grown in the area prior to this study, thus making it important to know if active nodulation were occurring. Nodule size and number have been associated with increased $\mathrm{N}$ fixation (Olayinka et al., 1998)

On 22 Aug. 1995 in Plymouth and 5 Sept. 1996 in Goldsboro, 1- $\mathrm{m}^{2}$ biomass samples from each of four replications were cut at the soil surface. The samples were separated into component cover crop species and broadleaf and grass weeds, dried at $65{ }^{\circ} \mathrm{C}$ for a minimum of $48 \mathrm{~h}$, and weighed to determine aboveground biomass. Samples were ground with a Tecator 1093 Cyclotec grinder (Perstorp Analytical Co., Hoganas, Sweden)

Table 2. Growth characteristics and environmental considerations of summer cover crops evaluated.

\begin{tabular}{|c|c|c|}
\hline Species & Growth characteristics & Environmental considerations \\
\hline \multicolumn{3}{|c|}{ Legumes/other } \\
\hline Cowpea & Viny $0.5-1 \mathrm{~m}$, stout taproot with laterals near surface & Tolerant of acidity, drought, intolerant of waterlogging \\
\hline Sesbania & 1-4 m, erect, shallow rooted & Tolerant of heavy, waterlogged soils and wide $\mathrm{pH}$ \\
\hline Trailing soybean & Upright \& viny, $0.6-1.2 \mathrm{~m}$, fibrous, most in top $0.2 \mathrm{~m}$ & Tolerant of wet and dry soils, variable $\mathrm{pH}$ \\
\hline Velvetbean & Viny, 3-18 m, fibrous roots & Intolerant of waterlogging, resistant to light frost, nematodes \\
\hline Lablab & Viny $0.5-2 \mathrm{~m}$, stout taproot with laterals near surface & Tolerant of acidity \& alkalinity, drought when established \\
\hline Hairy indigo & Erect \& spreading $0.6-2.5 \mathrm{~m}$ & Tolerant of acidity, intolerant of waterlogging \\
\hline Buckwheat & Erect $0.50-1.5 \mathrm{~m}$, taproot with laterals near surface & Intolerant of drought, waterlogged soils \\
\hline Sesame & Erect $1-1.5 \mathrm{~m}$ & \\
\hline \multicolumn{3}{|c|}{ Grasses } \\
\hline Japanese millet & Erect $0.6-1.2 \mathrm{~m}$, fibrous roots & Low biomass production under dry conditions \\
\hline German foxtail millet & $0.3-1.5 \mathrm{~m}$, fibrous roots & Heat tolerant, low water requirement but sensitive to extended drought \\
\hline Pearl millet & $0.3-4.5 \mathrm{~m}$, fibrous roots & Heat and drought tolerant, high production with new hybrids \\
\hline Sudangrass & Erect to $5 \mathrm{~m}$, fibrous roots & Drought, salinity and heat tolerant, sensitive to low temperatures \\
\hline Sorghum-sudangrass & Erect to $5 \mathrm{~m}$, fibrous roots & Drought tolerant, allelopathic, prussic acid problematic for livestock \\
\hline
\end{tabular}


and analyzed for $\mathrm{C}$ and $\mathrm{N}$ with a PerkinElmer Analyzer 2400 (Perkin-Elmer Corp., Norwalk, Conn.).

Data were subjected to analysis of variance, and least significant difference (LSD) tests were used to separate means (Wilkinson, 1990).

\section{Results and Discussion}

Rainfall for the growing season was 269 $\mathrm{mm}$ in Plymouth in 1995 and $531 \mathrm{~mm}$ in Goldsboro in 1996, whereas the 30-year average is $314 \mathrm{~mm}$ in Plymouth and $329 \mathrm{~mm}$ in Goldsboro. Two hurricanes (Bertha and Fran) contributed to the above-normal rainfall in 1996. Temperatures were near average in both seasons.

No nodules were present on lablab, which is reflected in the low biomass production of the crop (Table 3). Velvetbean had relatively few nodules, but those present were active. Cowpea and soybeans had moderate numbers of nodules, but only some were active. Sesbania was highly nodulated, and all nodules were active.

There was no interaction between site/ years, so data for monoculture species were combined for analysis (Table 4). The sesbania cover crop produced a high amount of biomass; however, its use as a cover crop should probably be discouraged in the southeastern United States because of its potential to be an important weed. Sesbania had a desirable $\mathrm{C}: \mathrm{N}$ ratio $(23: 1)$ and potential to contribute significant amounts of $\mathrm{N}\left(97 \mathrm{~kg} \cdot \mathrm{ha}^{-1}\right)$ for use by subsequent crops. Soybean produced $\approx 90$ $\mathrm{kg} \cdot \mathrm{ha}^{-1} \mathrm{~N}$ and may be the most economical choice for a summer legume cover crop because of its relatively low cost. Soybean did not compete as well with weeds as some of the other species, but inhibited weed growth relative to weedy control plots (Table 4). Cowpea was vigorous, competitive with weeds, and produced large amounts of biomass and N. Velvetbean germinated very poorly in this experiment, probably because the very large seed was damaged in the grain drill at planting. While biomass was high in buckwheat, the $\mathrm{C}: \mathrm{N}$ ratio was also high and $\mathrm{N}$ low as compared with many of the legumes. Though buckwheat may not supply as much $\mathrm{N}$ as the legumes, it has other benefits and has been reported to suppress weeds (Oplinger et al., 1989), attract beneficial insects (Bugg and Ellis, 1990), and accumulate $\mathrm{P}$ (Annan and Amberger, 1989). Sesame was vigorous, and, like buckwheat, had a higher C $: \mathrm{N}$ ratio and lower $\mathrm{N}$ accumulation than all of the legumes except lablab and velvetbean. It was competitive with weeds, and may also attract beneficial insects into cropping systems because of its flower structure. This crop warrants further evaluation as a summer cover crop. Nearly all of the broadleaf and legume summer cover crops reduced weeds as compared with the weedy control plots, except when cover crop biomass was extremely low (velvetbean). Hairy indigo produced no biomass in this study, as it was outcompeted because of slow emergence and establishment.

Table 3. Assessment ${ }^{\mathrm{Z}}$ of legume nodulation in Plymouth, N.C., on 7 Aug. 1995.

\begin{tabular}{lcccc}
\hline \hline Species & No. & Size & Location & Activity \\
\hline Cowpea & Medium & Medium & Tap and lateral roots & $50 \%$ active \\
Sesbania & High & Large & Tap and lateral roots & Active \\
Lablab & None & & & \\
Soybean & Medium & Medium & Tap and lateral roots & $50 \%$ active \\
Velvetbean & Few & Medium & Lateral roots & Active \\
\hline${ }^{\text {} A f t e r ~ S a r r e n t o n i o ~}$ & $(1991)$ & & &
\end{tabular}

Table 4. Aboveground biomass (AGB), $\mathrm{C}: \mathrm{N}$ ratio, and $\mathrm{N}$ in $\mathrm{AGB}$, for species grown in Plymouth, N.C., and Goldsboro, N.C., in 1995 and 1996.

\begin{tabular}{|c|c|c|c|c|}
\hline \multirow[b]{2}{*}{ Species } & \multicolumn{2}{|c|}{ Aboveground biomass $\left(\mathrm{kg} \cdot \mathrm{ha}^{-1}\right)$} & \multirow[b]{2}{*}{$\mathrm{C}: \mathrm{N}$} & \multirow[b]{2}{*}{ Nitrogen $\left(\mathrm{kg} \cdot \mathrm{ha}^{-1}\right)$} \\
\hline & Crop & Weed & & \\
\hline \multicolumn{5}{|c|}{ Legumes and other broadleaf species } \\
\hline Sesbania & $4807^{\mathrm{z}} \mathrm{cd}$ & $518 \mathrm{de}$ & 23 ef & $97 \mathrm{a}$ \\
\hline Soybean & $3940 \mathrm{~d}$ & $881 \mathrm{~cd}$ & $20 \mathrm{f}$ & $90 \mathrm{ab}$ \\
\hline Sesame ${ }^{y}$ & 3766 & 220 & 34 & 46 \\
\hline Cowpea & $3966 \mathrm{~d}$ & $187 \mathrm{e}$ & $21 \mathrm{f}$ & $84 \mathrm{ab}$ \\
\hline Trailing soybean & 3704 de & 339 de & $21 \mathrm{f}$ & $79 \mathrm{ab}$ \\
\hline Buckwheat & 3548 def & $310 \mathrm{de}$ & $21 \mathrm{f}$ & $48 \mathrm{~cd}$ \\
\hline Lablab & 2241 ef & $1371 \mathrm{bc}$ & $34 \mathrm{~d}$ & $35 \mathrm{~d}$ \\
\hline Velvetbean & $1420 \mathrm{f}$ & $1951 \mathrm{ab}$ & $29 \mathrm{de}$ & $32 \mathrm{~d}$ \\
\hline \multicolumn{5}{|c|}{ Grasses } \\
\hline Sorghum-sudangrass & $8792^{z} a$ & $54 \mathrm{e}$ & $53 \mathrm{a}$ & $88 \mathrm{ab}$ \\
\hline Pearl millet & $6670 \mathrm{~b}$ & $69 \mathrm{e}$ & $50 \mathrm{ab}$ & $65 \mathrm{bc}$ \\
\hline Sudangrass & $5639 \mathrm{bc}$ & $81 \mathrm{e}$ & $44 \mathrm{bc}$ & $66 \mathrm{bc}$ \\
\hline German foxtail millet & $4569 \mathrm{~cd}$ & $254 \mathrm{de}$ & $44 \mathrm{bc}$ & $48 \mathrm{~cd}$ \\
\hline Japanese millet & $3918 \mathrm{~d}$ & $161 \mathrm{e}$ & $42 \mathrm{c}$ & $39 \mathrm{~cd}$ \\
\hline Weedy control & & $2185 \mathrm{a}$ & & \\
\hline $\mathrm{LSD}_{0.05}$ & 1607 & 644 & 7 & 29 \\
\hline
\end{tabular}

${ }^{\mathrm{z}}$ Mean separation within columns by LSD at $P \leq 0.05$.

${ }^{\mathrm{y}}$ Sesame was not included in the statistical analysis as it was only present at one site.

Sorghum-sudangrass produced the highest amount of aboveground biomass and was very competitive with weeds (Table 4$)$. The $\mathrm{C}: \mathrm{N}$ ratio was very high (53), so while the amount of $\mathrm{N}$ in the aboveground biomass was substantial $\left(88 \mathrm{~kg} \cdot \mathrm{ha}^{-1}\right)$, immobilization of $\mathrm{N}$ would need to be overcome for use with a fall-planted vegetable crop. $\mathrm{C}: \mathrm{N}$ ratios for the grasses were high, and additional $\mathrm{N}$ would probably be required to overcome immobilization. The most vigorous grass cover crops effectively suppressed weeds, and all of them reduced weeds as compared with the weedy control plots.

Because there was little repetition of tested mixtures between years, data were analyzed separately for each year. Because of poor germination, hairy indigo and velvetbean did not perform well in the mixture combinations in 1995 (Table 5), so mixtures that contained these species were not tested in 1996. The mixture of sorghum-sudangrass and cowpea performed consistently at both sites during both years, with high biomass, high biomass $\mathrm{N}$, and little weed growth. The inclusion of cowpea reduced the $\mathrm{C}: \mathrm{N}$ ratio substantially (Table 5). Japanese millet and soybean performed well as a mixture, with significant amounts of biomass from both species present in the mixture. This mixture produced 91 $\mathrm{kg} \cdot \mathrm{ha}^{-1} \mathrm{~N}$ in Plymouth and $57 \mathrm{~kg} \cdot \mathrm{ha}^{-1} \mathrm{~N}$ in Goldsboro. All mixtures were competitive with weeds relative to the weedy control plots, except for the sesbania/velvetbean mixture (which was entirely sesbania). The seeding rate for sesbania in the mixture was much lower than the monoculture seeding rate, which explains the low biomass of sesbania and resulting high weed biomass.

Summer cover crops have the potential to produce large amounts of biomass that will build soil quality in a short time. At the same time, they contribute or recycle N, minimize weed growth, and reduce soil erosion by keeping the soil surface covered. This study demonstrates that there are viable choices for short-season summer cover crops in the southeastern United States. Some of them may also have the potential to be mechanically killed and left on the surface as a mulch for no-till vegetable production in the fall. Creamer and Dabney (1999) evaluated these crop's susceptibility to various methods of mechanical kill and found that undercutting provided greater than $95 \%$ kill for five of six broadleaf species and two of five grass species. Mowing was effective in killing all six broadleaf species, but regrowth occurred with three of five grasses, with no regrowth in the mature German foxtail millet and Japanese millet. In general, rolling did not effectively kill broadleaves or grasses, unless they were mature (German foxtail millet, Japanese millet and buckwheat).

Mixtures have great potential to optimize benefits of cover crop use, but additional research should be conducted to select appropriate mixture combinations and determine seeding rates for optimum production. Research is also needed to determine the optimum time of cover crop establishment and kill and the subsequent effect on cash crops planted into cover crops that are killed and either left on the soil surface or incorporated. 
Table 5. Percent composition, aboveground biomass (AGB), C:N ratio, and N in AGB for cover crop mixtures grown in Plymouth and Goldsboro in 1995 and 1996, respectively.

\begin{tabular}{|c|c|c|c|c|c|}
\hline \multirow[b]{2}{*}{ Species } & \multicolumn{5}{|c|}{ Aboveground biomass $\left(\mathrm{kg} \cdot \mathrm{ha}^{-1}\right)$} \\
\hline & Composition (\%) & Crop & Weed & $\mathrm{C}: \mathrm{N}$ & $\mathrm{N}\left(\mathrm{kg} \cdot \mathrm{ha}^{-1}\right)$ \\
\hline \multicolumn{6}{|c|}{ Plymouth } \\
\hline Sorghum-sudangrass/cowpea & $79 / 21$ & $7879 \mathrm{ab}^{2}$ & $184 \mathrm{a}$ & $39 \mathrm{c}$ & $91 \mathrm{a}$ \\
\hline Japanese millet/soybean & $47 / 53$ & $4799 \mathrm{c}$ & $139 \mathrm{a}$ & $28 \mathrm{~d}$ & $91 \mathrm{a}$ \\
\hline Sudangrass/hairy indigo & $99 / 1$ & $6780 \mathrm{bc}$ & $190 \mathrm{a}$ & $74 \mathrm{a}$ & $42 \mathrm{~b}$ \\
\hline Pearl millet/velvetbean & $92 / 8$ & $5504 \mathrm{c}$ & $70 \mathrm{a}$ & $58 \mathrm{~b}$ & $42 \mathrm{~b}$ \\
\hline Sorghum-sudangrass/velvetbean & $99 / 1$ & 9889 a & $316 \mathrm{a}$ & $59 \mathrm{~b}$ & $76 \mathrm{a}$ \\
\hline Weedy check & & & $2783 \mathrm{~b}$ & & \\
\hline $\mathrm{LSD}_{0.05}$ & & 2287 & 299 & 10 & 30 \\
\hline \multicolumn{6}{|c|}{ Goldsboro } \\
\hline Sorghum-sudangrass/soybean (tr.) & $96 / 4$ & $10650 \mathrm{a}$ & $207 \mathrm{a}$ & 24 & $201 \mathrm{a}$ \\
\hline Sorghum-sudangrass/cowpea & $79 / 21$ & $8001 \mathrm{~b}$ & $50 \mathrm{a}$ & 28 & $102 \mathrm{~b}$ \\
\hline Cowpea/sesbania & $72 / 28$ & $3910 \mathrm{c}$ & $117 \mathrm{a}$ & 28 & $64 \mathrm{bc}$ \\
\hline Japanese millet/soybean & $27 / 73$ & $3051 \mathrm{c}$ & $543 \mathrm{a}$ & 23 & $57 \mathrm{bc}$ \\
\hline Sesbania/velvetbean & $100 / 0$ & $2849 \mathrm{c}$ & $1830 \mathrm{~b}$ & 28 & $25 \mathrm{c}$ \\
\hline Weedy check & $2163 \mathrm{~b}$ & & & & \\
\hline $\mathrm{LSD}_{0.05}$ & & 2446 & 1406 & NS & 51 \\
\hline
\end{tabular}

${ }^{2}$ Mean separation within columns, by LSD at $P \leq 0.05$.

NS Nonsignificant at $P \leq 0.05$.

\section{Literature Cited}

Annan, C. and A. Amberger. 1989. Phosphorous efficiency of buckwheat (Fagopyrum esculentum). Zeits. for Pflanzenern a hrung und Bodenkunde. 152:181-189.

Barber, R.G. and F. Navarro. 1994. The rehabilitation of degraded soils in eastern Bolivia by subsoil and the incorporation of cover crops. Land Degradation Rehabilitation 5:247-259.

Beri, V., O.P. Meelu, and C.S. Khind. 1989. Biomass production, $\mathrm{N}$ accumulation, symbiotic effectiveness and mineralization of green manures in relation to yield of wetland rice. Trop. Agr. 66:11-16.

Bugg, R.L. and R.T. Ellis. 1990. Insects associated with cover crops in Massachusetts. Biol. Agr. and Hort. 7:47-68.

Clement, A., J.K. Ladha, and F.P. Chalifour. 1995 Crop residue effects on nitrogen mineralization, microbial biomass, and rice yield in submerged soils. Soil Sci. Soc. Amer. J. 59:1595-1603.

Creamer, N.G. and S. Dabney. 2000. Non-chemical methods for killing cover crops. J. Alt. Agr. (In Press.)

Creamer N.G., M.A. Bennett, and B.R. Stinner. 1997. Evaluation of cover crop mixtures for use in vegetable production systems. HortScience 32:866-870.

Creamer, N.G., M.A. Bennett, B.R. Stinner, and J. Cardina. 1996. A comparison of four processing tomato production systems differing in cover crop and chemical inputs. J. Amer. Soc. Hort. Sci. 121:559-568.

Crow W.T., E.A. Guertal, E.A. Rodriguez, and R. Kabana. 1996. Responses of Meloidogyne arenaria and $M$. incognita to green manures and supplemental urea in glasshouse culture. J. Nematol. 28:648-654.

Einhellig, F.A., J.A. Rasmussen, and A.M. Hejl. 1993. Effects of root exudate sorgoleone on photosynthesis. J. Chem. Ecol. 19:369-375.
Flach, KW. 1990. Low-input agriculture and soil conservation. J. Soil Water Conserv. 45:4244.

Franzluebbers, K., R.W. Weaver, and A.S.R. Juo. 1994. Mineralization of labeled-N from cowpea (Vigna unguiculata (L) Walp) plant parts at 2 growth stages in sandy soil. Plant Soil 160:259266.

Giller, K.E., and G. Cadisch. 1995. Future benefits from biological nitrogen fixation-An ecological approach to agriculture. Plant Soil 174:255277.

Hoyt, G.D., D.W. Monks, and T.J. Monaco. 1994 Conservation tillage for vegetable production. HortTechnology 4:129-135.

Knavel, D.E. and J.W. Herron. 1985. Effect of sudangrass on yield and elemental content of cabbage. HortScience 20:680-689.

Mansoer, Z., D.W. Reeves, and C.W. Wood. 1997. Suitability of sunnhemp as an alternative latesummer legume cover crop. Soil Sci. Soc. Amer. J. 61:246-253.

McGill, W.B. and R.J.K. Myers. 1987. Controls on dynamics of soil and fertilizer nitrogen. Spec. Publ. Soil Sci. Soc. Amer. 19:73-99.

McSorley R. and D.W. Dickson. 1995. Effect of tropical rotation crops on Meloidogyne incognita and other plant-parasitic nematodes. J. Nematol. 27:535-543.

McSorley, R., D.W. Dickson, and J.A. Debrito. 1994. Effects of tropical rotation crops on Meloidogyne arenaria population densities and vegetable yields in microplots. J. Nematol. 26:175-181.

Mojtahedi, H., G.S. Santo, and R.E. Ingham. 1993. Suppression of Meloidogyne-chitwoodi with sudangrass cultivars as green manure. J. Nematol. 25:303-311

Olayinka, A., A.Adetunji, and A. Adebaya. 1998. Effect of organic amendments on nodulation and nitrogen fixation by cowpea. J. Plant Nutr. 21:2455-2464.
Oplinger, E.S., E.A. Oelke, M.A. Brinkman, and K.A. Kelling. 1989. Buckwheat, p. 1-7. In: E.S. Oplinger and E.A. Oelke (eds.). Alt. Field Crops Manual. Univ. Wisconsin, Extension, Madison.

Peoples, M.B., D.F. Herridge, and J.K. Ladha. 1995. Biological nitrogen fixation-and efficient source of nitrogen for sustainable agricultural production. Plant Soil 174:3-28.

Sanford, J.O. and J.E. Hairston. 1984. Effects of N (nitrogen) fertilization on yield, growth, and extraction of water by wheat following soybeans and grain sorghum. Agron. J. 76:623-627.

Sarrantonio, M. 1991. Methodologies for screening soil improving legumes. Rodale Inst., Kutztown, $\mathrm{Pa}$.

Schonbeck, M., J. Browne, G. Deziel, and R. DeGregoria. 1991. Comparison of weed biomass and flora in four cover crops and a subsequent lettuce crop on three New England organic farms. Biol. Agr. Hort. 8:123-143.

Stivers, L.J. and C. Shennan. 1989. Winter cover cropping in processing tomato production, $\mathrm{p}$. 254. (Abstr.). Amer. Soc. Agron., Crop Sci. Soc. Amer., Soil Sci. Soc. Amer., Madison, Wis

Teasdale, J.R. 1993. Interaction of light, soil-moisture, and temperature with weed suppression by hairy vetch residue. Weed Sci. 41:46-51.

Wagger, M.G. 1989. Time of desiccation effects on plant composition and subsequent nitrogen release from several winter annual cover crops. Agron. J. 81:236-241.

Weston, L.A., R. Harmon, and S. Mueller. 1989. Allelopathic potential of sorghum-sudangrass hybrid (Sudex). J. Chem. Ecol. 15:1855-1865.

Wilkinson, L. 1990. SYSTAT. The system for statistics. SYSTAT, Evanston, Ill.

Wilson, G.F., R. Lal, and B.N. Okigbo. 1982. Effects of cover crops on soil structure and on yield of subsequent arable crops grown under strip tillage on an eroded alfisol. Soil and Tillage Res. 2:233-250. 